УДК 347.22 .02

DOI https://doi.org/10.32837/apdp.v0i86.2403

М. М. Гудима

\title{
НАУКОВИЙ ДИСКУРС ЩОДО МІСЦЯ ПЕРЕДАЧІ РЕЧІ В МЕХАНІЗМІ ДОГОВІРНОГО ПЕРЕХОДУ ПРАВА ВЛАСНОСТІ
}

Постановка проблеми. Сучасна правова доктрина характеризується актуалізацією наукової уваги на розрізненні та співвідношенні зобов'язального та речового договорів як підстав для переходу речового права. Очевидно, що передача речі $\epsilon$ юридично значущою обставиною в договірних відносинах щодо переходу права власності, однак яке саме юридичне значення вона відіграє - питання неоднозначне. Перший погляд на проблему зводиться до того, що право власності виникає на підставі та у зв'язку з виконанням договору, який встановлює відповідні зобов’язання (передати речове право), тоді як інший - обстоює, що право власності переходить на підставі окремого правочину, ціль якого становить передача речі (речовий договір). До того ж у рамках останнього підходу обгрунтовується відсутність юридичного зв'язку між правочином щодо передачі речі та договором, на підставі якого виникає зобов'язання щодо такої передачі. Як наслідок, це означає, що визнання договору недійсним жодним чином не впливатиме на правочин щодо передачі речі та його речовий ефект - перехід права власності.

Тож вказана проблематика вже отримує практичну площину, адже впирається у формулювання відповіді на запитання: чи залежить перехід власності через передачу від дійсності підстави, відповідно до якої така передача відбулася?

Саме тому створення загального аналітичного інструментарію шляхом теоретичного пояснення й обгрунтування місця та значення передачі речі в механізмі договірного переходу права власності вбачаємо необхідним у руслі прагнення до вдосконалення цивільного законодавства та практики його реалізації.

Ступінь наукової розробки теми. Проблематика переходу речових прав за договором, зокрема й питання значення передачі речі, виявлення особливостей її моделей (абстрактна та каузальна) була предметом досліджень чималої кількості науковців, зокрема: Р.С. Бевзенка, В.В. Бердникова, Л.Ю. Василевської, В.В. Грачова, І.О. Смелькіної, Д.С. Спесівцева, Є.О. Суханова, Д.О. Тузова, О.А. Халабуденка, Є.О. Харитонова, Г.Г. Харченка, C.I. Шимон та інших. Проте чималий науковий інтерес до вказаної проблематики не зміг поставити остаточну крапку в науковій дискусії щодо співвідношення договору та передачі речі, їхнього місця в механізмі переходу речових прав, не позначився на актуальності даної проблематики для сучасної цивілістики.

Мета наукової публікації полягає в з'ясуванні значення передачі речі в руслі теоретичного вчення про юридичні факти, дослідження її місця в механізмі договірного переходу права власності.

Виклад основного матеріалу. Коли говоримо про перехід права власності, як таке набуття права власності (і припинення його в попереднього власника), яке базується на залежності виникнення права наступного власника від наявності

(C) М. М. Гудима, 2020 
права у власника попереднього, відзначимо, що найчисленнішу групу юридичних фактів становлять договори, оскільки в більшості випадків перехід права власності на майно відбувається на їх підставі. I.P. Калаур уважає, що як юридична підстава для виникнення права власності договір має особливі ознаки, які відрізняють його від інших юридичних фактів, що є підставами для набуття цього речового права: по-перше, цивілістичній науці невідомі інші правові конструкції, які б виражали погодження волі відчужувача і волі набувача на передачу майна у власність; по-друге, договір є підставою для набуття у власність майна, яке вже має власника; по-третє, договір є основою водночас двох правових явищ: припинення права власності у відчужувача та виникнення цього права в набувача. Отже, договір є не тільки підставою для виникнення права власності, але й правовим механізмом динаміки цього речового права від власника майна до його набувача [1, с. 9].

Незважаючи на вагоме значення договору як підстави для переходу права власності та серйозний науковий інтерес до даної проблематики, відзначимо, що вона не позбавлена дискусійних моментів, як-от вирішення питання: чи може договір слугувати самостійним юридичним фактом, що веде до переходу права власності, чи потрыбна ще й передача речі, тобто необхідний цілий юридичний склад для настання відповідних правових наслідків?

У відомому підручнику Д.І. Мейєра «Русское гражданское право» відзначається необгрунтованим розгляд договору як способу набуття майна, вказується, що «законна підстава для передачі встановлює лише право на передачу, а передача вже становить спосіб набуття самого права власності» [2, с. 62]. Аналогічна позиція і Г.Ф. Шершеневича, який стверджував: «За необхідність передачі як фізичного акту говорять різні міркування теоретичного і практичного характеру. <...> Договору за його сутністю чуже встановлення речового зв'язку - він створює лише право вимоги» [3, с. 183]. Необхідним, на думку дослідника, є ще один акт, саме передачу речі він розцінював як юридичний факт, що породжує набуття права власності, тоді як договір є тільки підставою для даного факту [3, с. 185]. Подібна думка трапляється і в сучасних наукових дослідженнях у царині набуття права власності. Так, Л.В. Саннікова вважає, що укладення договору купівлі-продажу породжує в покупця не право власності, а лише право вимагати передачі речі. Право власності, за загальним правилом, виникає в момент передачі речі. Дослідниця наголошує, що нерозуміння цього може призвести до помилок у правозастосуванні [4, с. 179, 183].

Природно виникає комплекс запитань: чи слугує договір, укладений сторонами, юридичним фактом для іншого юридичного факту - передачі речі; матиме він значення самостійного юридичного факту чи перед нами ланцюг із декількох юридичних фактів, зазвичай іменований у теорії права «юридичним складом»; чи має передача речі значення самостійного правочину, що може застосовуватися і поза зв'язком із договором?

Аналіз спеціальної літератури дозволяє стверджувати, що більшість учених, які досліджували проблему, визнавали передання самостійним правочином. Одним із нечисленної групи противників цього виступав Б.Б. Черепахін, який пояснював свою позицію тим, що без «відчужувального договору» роль передачі речі є незначною, вона виступає лише елементом складного юридичного складу [5, с. 347]. 
В.В. Бердников у дослідженні так званих розпорядчих правочинів (до них він відносить, зокрема, традицію (передача речі) і цесію), підкреслює, що традиція (передача речей) є правочином, здатним безпосередньо змінити майновий стан сторін, є правочином абстрактним [6, с. 16-22].

У сучасній вітчизняні літературі розпорядчим визнається такий правочин, що вчиняється у процесі виконання зобов'язання й опосередковує перенесення майнового суб'єктивного права (речового, зобов'язального) від однієї особи до іншої. Розпорядчий правочин розглядається як самостійний, безповоротний і абстрактний [7, с. 1048]. Видом розпорядчого вважається "речовий правочин» - як волевиявлення, яке безпосередньо спричиняє втрату чи обтяження права або перехід чи обтяження встановленого раніше речового права [8, с. 12].

На суттєвих логічних суперечностях у разі визнання самостійності розпорядчого правочину (передання речі) акцентує увагу C.I. Шимон. Дослідниця методом від зворотного аналізує, якщо трактувати, наприклад, передання речі самостійним правочином, то його правовий наслідок - виникнення права власності - не має збігатися з наслідком головного правочину, на підставі якого здійснюється передання речі. Звідси варто було б уважати, що правочин із купівлі-продажу має на меті виникнення обов'язків із передання речі, але ще не виникнення права власності (що є метою іншого, «паралельного» правочину з передання речі). Це б означало, що договір купівлі-продажу речі укладається заради самого договору, бо з моменту, коли він дійсний, він уже досяг своєї мети, оскільки обов'язок передати річ виник на його підставі. У такому договорі не було б ні юридичного, ні соціального сенсу. Здійснення обов'язків, що виникли на підставі правочину, підпорядковане меті правочину й не має власної самостійної мети, як пише дослідниця [7, с. 1049].

Під час вирішення питання про значення передачі речі доцільно згадати про спір, що своїм корінням сягає ще римського права, щодо можливості визнання передачі речей каузальним або абстрактним правочином [9, с. 188-190]. Зрозуміло, що за підтримання концепції каузальності передачі речі остання розглядається залежною від дійсності підстави для передачі (каузи). У другому разі (за абстрактності) намір сторін передати і прийняти право власності матиме самодостатне значення і не залежить від того, що саме малося на увазі кожною зі сторін як підстава для передачі. Прихильником другої (абстрактної) теорії був ще Ф.К. фон Савіньї, який стверджував, що коли надається милостиня жебраку право власності на монету, безсумнівно, передається через традицію, однак ні до, ні після цього акту жодного зобов'язання не існувало; так само і коли хтось просить позичити грошей і я передаю йому цю суму, не будучи попередньо зобов'язаний це робити [10, с. 527]. Подібний підхід висловлював і Г.Ф. Пухта, який зазначав, що в разі дарування не передує жодний justus titulus у формі jus ad rem, жодне зобов’язання, оскільки titulus тут збігається із традицією. Необхідно відмовитися від визначення титулу в сенсі зобов'язання, тому що сам титул має визначатися лише як незобов'язальна юридична вимога, що передує традиції [11, с. 381].

Вирішення питання щодо підтримання абстрактної чи каузальної моделей передачі речі лише на перший погляд є суто теоретичним, адже у практичній площині його вирішення означатиме, чи залежатиме перехід права власності через передачу 
речі від дійсності підстави, відповідно до якої така передача відбулася, чи ні, і які наслідки наступатимуть у разі недійсності правової підстави переходу (недійсність договору)? У разі підтримання абстрактної моделі на практиці цілком могло трапитися так, що суб’єкт, який передає річ, припускає передачу через купівлю-продаж, а суб'єкт, що приймає річ, сприймає передачу як дарування. «Один помилково передає іншому неналежне (indebitum), сплачує водночас борг, якого немає; у цьому разі traditio дійсна - право власності переходить на іншу особу». В.В. Єфімов додає, що в першої особи немає права на віндикацію, вона може лише вимагати відшкодування збитку в розмірі безпідставного збагачення [12, с. 322].

Існування таких позовів дещо рятує ситуацію за умови абстрактності передачі. У практичному ракурсі ситуацію дещо спростила б правова конструкція визнання чужим майна, що переходить за будь-якого відчужувального правочину, чим підтримувалася б ідея неможливості нівелювання передачі речі намірами сторін. Проте така конструкція сприяла б спрощенню лише у практичній сфері, отже, у теоретичному плані, навпаки, - породила б новий клубок суперечностей. Тому не варто уникати вирішення насущних теоретичних проблем шляхом моделювання додаткових конструкцій, які не можуть усунути проблему загалом.

Видається, що натепер у чинній правовій системі немає підстав розглядати передання речі абстрактним правочином, відриваючи його від каузи. До того ж підхід вітчизняного законодавця базується на підтриманні саме каузальної моделі переходу речових прав за договором, про що свідчить зміст ч. 1 ст. 216 Цивільного кодексу (далі - ЦК) України, згідно з якою недійсний правочин не створює юридичних наслідків, крім тих, що пов'язані з його недійсністю. У разі недійсності правочину кожна зі сторін зобов'язана повернути другій стороні в натурі все, що вона одержала на виконання цього правочину, а в разі неможливості такого повернення, зокрема тоді, коли одержане полягає в користуванні майном, виконаній роботі, наданій послузі, відшкодувати вартість того, що одержано, за цінами, які існують на момент відшкодування. Тобто в разі, якщо між сторонами був укладений договір із суттєвими вадами, що здатні спричинити визнання його недійсним, то й передання речі на виконання такого договору не спричинить переходу права власності на вже передану річ.

Отже, не можемо оцінювати передачу речі як абстрактну й вільну від намірів, виражених у договорі; у відриві від договору або іншого юридичного факту, наприклад, адміністративного акта, будь-яка передача не повинна розглядатися самодостатньою, бо така безлика і безцільова дія, що не спирається на волю сторін, призведе лише до нових непорозумінь і суперечок.

Визначившись із каузальною природою правочину щодо передачі речі, надалі вирішимо питання з можливістю надання йому самостійного значення в механізмі переходу права власності чи іншого речового права. Варто звернути увагу на те, що прихильники самостійного значення правочину щодо передачі речі переважно здійснювали обгрунтування цього у ключі реальних договорів, у яких момент набуття чинності збігається з передачею речі, що, як наслідок, дає можливість говорити про деяку самостійність та відокремленість передачі речі як юридичного факту, що спричиняє відповідні правові наслідки у вигляді переходу права власності. Однак, з огляду на принцип свободи договору, сторони можуть укладати і консенсуальні 
договори, які вважаються чинними з моменту їх укладення, а тому передача речі за ними є елементом виконання даного договору, а отже, сама собою без правової підстави - договору - не здатна створювати самостійні правові наслідки. Тому у вказаних договорах зв'язок між правовою підставою (договором) та передачею речі є очевиднішим, ніж у реальних договорах. Проте в останніх такий зв'язок також наявний, що підтверджується тезою М.О. Церковнікова: «Реальний договір не може з'явитися раніше передачі (відповідно до закону), передача не може бути раніше підстави (договору), одночасна ж їх «поява» суперечить їх «суті» [13, с. 20-28].

Отже, якщо стосовно самостійного значення консенсуального договору як юридичного факту переходу права власності сумнівів не виникає, то у спектрі аналізу реального договору це потребує додаткового обгрунтування.

Деякі автори не надають самостійного значення передачі речі як окремому правочину, кваліфікують таку передачу як елемент договору [14, с. 17] Скажімо, Г.Г. Харченко говорить про складну подвійну структуру договору щодо переходу, наприклад, права власності на майно, яка передбачає наявність і укладення принаймні двох двосторонніх правочинів, з яких один породжує між сторонами певні права й обов'язки, а другий безпосередньо спрямований на їх реалізацію, тобто на виконання договору. Перша безпосередньо пов'язана із зобов'язальною частиною договору, друга - з речовою [15, с. 46].

Проте в літературі трапляється і протилежна позиція, яка розділяє договір та передачу речі як різні юридичні факти - елементи фактичного складу, здатного спричинити відповідні правові наслідки у вигляді переходу речового права. Обгрунтування такої тези полягає в тому, що будь-який договір - це consensus, його укладення відбувається у формі волевиявлення і в момент його здійснення. Реальний договір і до передачі речі треба вважати укладеним [16, с. 540], але не таким, що породжує правові наслідки. Оскільки договір - обмін волевиявленнями, то до його складу нічого, крім власне волевиявлень, входити не може. Передача речі не є волевиявленням, тому до складу «обміну волевиявленнями не входить», iï науковці відносять до зовнішніх обставин, наявність яких може мати значення для дійсності правочину, однак не до елементів договору [17, с. 13-14].

Справді, у склад і реальних, і консенсуальних договорів входять волевиявлення сторін та потребується їх узгодження. Згідно із ч. 1 ст. 638 ЦК України, договір є укладеним, якщо сторони в належній формі досягли згоди з усіх істотних умов договору. Дотримуючись загальної презумпції консенсуальності договорів, текстуально визначивши іï в ч. 1 ст. 640 ЦК України: договір є укладеним із моменту отримання особою, яка направила пропозицію укласти договір, відповіді про прийняття цієї пропозиції, усе ж законодавець передбачив винятки, закріпив, якщо відповідно до акта цивільного законодавства для укладення договору необхідні також передання майна або вчинення іншої дії, договір є укладеним із моменту передання відповідного майна або вчинення певної дії (ч. 2 ст. 640 ЦК України). Саме в моменті, з якого договір уважається укладеним, і знаходиться класифікаційний критерій розрізнення цивільно-правових договорів на консенсуальні та реальні.

За реальної моделі договору, як пише О.С. Яворська, непередання майна має наслідком неукладення договору. Якщо ж договір не укладений, то не може йтися про 
встановлення, зміну чи припинення прав та обов'язків його сторін, про застосування будь-яких засобів захисту в разі непередання майна чи невчинення іншої дії і поготів [18, с. 170]. Зрештою, неукладений договір більшістю дослідників-правників розглядається як такий, що не відбувся, тобто не існує як юридичний факт, що породжує певні права й обов’язки у сторін. Один із перших дореволюційних російських дослідників цього питання, Г.Ф. Шершеневич, виходив з того, що угода, яка не відбулася, має місце тоді, коли сторони не дійшли повної згоди, необхідної для чинності угоди [3, с. 172].

Безумовно, досягнення згоди 3 істотних умов договору $\epsilon$ обов'язковим для визнання договору укладеним, адже це насамперед зумовлено юридичною природою поняття договору як взаємної домовленості сторін, спрямованої на встановлення, зміну та припинення цивільних прав і обов’язків (ч. 1 ст. 626 ЦК України). Проте, як влучно пише С.С. Полченко, коли тлумачить ст. 640 ЦК України, законодавець збільшує перелік вимог і критеріїв, за якими договір може визнаватись укладеним. Крім умов про узгодження сторонами істотних вимог, висуваються вимоги до форми договорів або щодо виконання певних умов / дій, які становлять зміст цих договорів [19, с. 738].

Отже, можемо констатувати, що навіть за досягнення домовленості сторонами договору шляхом узгодження всіх істотних умов договору, без учинення дії-передання речі, якщо договір має реальний характер, він уважатиметься неукладеним, тобто таким, що не існував, не відбувся. Як наслідок, до передачі речі і як такого реального договору не існує, а тому говорити про існування окремих юридичних фактів - договору як домовленості та вольової дії - передачі речі, теоретично неправильно. Передача речі для реального договору є невід'ємним елементом фактичного складу самого договору.

Слушним є уточнення Є.В. Титова, якщо правові наслідки в консенсуальному договорі виникають безпосередньо за досягнення згоди, то у фактичний склад реального договору (підкреслення наше -. . Г.) додається ще один юридичний факт - передача речі [20, с. 151-156]. Саме з передачею речі пов'язується існування реального договору, зумовлюється його здатність породжувати відповідні правові наслідки.

Висновки. У підсумку нашого дослідження відзначимо, що договір є самостійним юридичним фактом, що здатен спричинити перехід права власності чи іншого речового права, хоча сам може мати складну структуру, елементами якої можуть виступати передача речі чи інші фактичні дії.

Зауважимо, що передача речі не тотожна передачі права власності, оскільки для передачі титулу зазвичай, потрібне взаємне волевиявлення сторін. Тому переважно за договором, якому властива ця якість, відбувається перехід права власності. Договір є самостійним юридичним фактом у механізмі переходу права власності й іншого речового права, становить одну з найпоширеніших юридичних підстав.

Погоджуємося з позицією Д.С. Спесівцева, що в реальному договорі передача речі - справді правовстановлювальний юридичний факт, посередництвом якого виникає сам договір і речове право в набувача, тоді як у консенсуальному договорі передача речі - виконання обов'язку, передбаченого договором, така передача перебуває в межах зобов'язального правовідношення. Тому слушно підсумовує автор, що важко вести тут мову про передачу речі як самостійний 
правочин, особливо з огляду на те, що право на таку річ уже має виникнути в набувача через саму конструкцію консенсуального договору [21, с. 128].

Усе це дає можливість здійснити підтримання каузальної моделі передачі речі, розглядати останню (передачу речі) не як самостійну та відірвану від правової підстави дію, здатну спричинити перехід речового права, а як елемент юридичного факту - договору, що тільки разом з останнім здатна спричинити перехід права власності (для реального договору). Договір незалежно від моменту укладення (реального чи консенсуального характеру) є самодостатнім юридичним фактом у переліку підстав для переходу права власності чи іншого речового права.

\section{Jimepamypa}

1. Калаур I.P. Цивільно-правовий договір як підстава виникнення права власності юридичної особи : автореф. дис ... канд. юрид. наук: 12.00.03. Львів, 2004. 20 с.

2. Мейер Д.И. Русское гражданское право -х : в 2 ч. Москва : Статут, 1997. Ч. 2. 455 с.

3. Шершеневич Г.Ф. Учебник русского гражданского права. Москва, 1995. 556 с.

4. Вонороніна Н.В. Підстави та способи набуття права власності. Актуальні проблеми держави $i$ права. 2010. Вип. 53. С. 179-185.

5. Черерпахин Б.Б. Правопреемство по советскому гражданскому праву. Москва : Госюриздат, $1962.162 \mathrm{c}$.

6. Бердников В.В. Распорядительная сделка как способ изменения имущественно-правового положения лица. Законодательство. 2002. № 2. С. 16-22.

7. Шимон C.I. Відчуження майнового права та концепт речового (розпорядчого) правочину в цивільному праві. Форум права. 2011. № 2. С. 1048-1054.

8. Capelle K.-H. Biirgerliches Recht. Sachenrecht. Betriebswirtschaftlicher Verlag Dr. Th. Gabler. Wiesbaden, 1963. 145 p.

9. Римское частное право : учебник / под ред. И.Б. Новицкого, И.С. Перетерского. Москва : Юристъ. 2004. 314 с.

10. Савиньи Ф.К. Обязательственное право. Пер. с нем. В. Фукс, Н. Мандро. Москва, 1876. 620 с.

11. Пухта Г.Ф. Курс римского гражданского права. Пер. с нем. Москва, 1874. Т. 1. 550 с.

12. Ефимов В. В. Догма римского права : учебный курс. Санкт-Петербург : Кн. маг. А.Ф. Цинзерлинга, б. Мелье и Ко, 1901. 640 с.

13. Церковников М.А. Признание договора незаключенным. Когда суд сохранит договорные отношения. Арбитражная практика. 2014. № 5. С. 20-28.

14. Грачев В.В. Правовая природа традиции. Сборник статей к 55-летию Е.А. Крашенинникова : сборник научных трудов. Ярославль : ЯрГУ, 2006. С. 16-35.

15. Харченко Г.Г. Перехід речових прав за договором (каузальна та абстрактна моделі). Підприємниитво, господарство і право. 2019. № 1. С. 45-49.

16. Savigny F.K. von. System des heutigen $r$ mischen Rechts. 2. Ausg. Darmstadt : Gentner, 1956. $540 \mathrm{~s}$.

17. Варул П.А. Волеизъявление и сделка. Сборник статей к 55-летию Е.А. Крашенинникова : сборник научных трудов. Ярославль : ЯрГУ, 2006. С. 7-15.

18. Яворська О.С. Реальні договори в цивільному праві України. Актуальні проблеми держави $i$ права. 2013. Вип. 70. С. 169-175.

19. Полченко С.С. Неукладений договір за законодавством України. 2010. № 4. С. 736-740.

20. Титов Е.В. О понятии юридического поступка в гражданском праве. Реализация и защита гражданских прав и законных интересов граждан и юридических лии в свете реформирования гражданского законодательства Российский Федерации : материалы Всероссийской научно-практической конференции. Иркутск : Изд-во ИГУ, 2014. С. 151-156.

21. Спесівцев Д.С. Передача нерухомої речі як юридичний факт. Науковий вісник Міжнародного гуманітарного університету. Серія «Юриспруденція». 2016. № 22. С. 126-128. 


\section{Анотація}

Гудима М. М. Науковий дискурс щодо місця передачі речі в механізмі договірного переходу права власності. - Стаття.

Наукова публікація присвячена правовому аналізу значення передачі речі в руслі теоретичного вчення про юридичні факти, дослідженню її місця в механізмі договірного переходу права власності. У статті формулюється відповідь на запитання: чи може договір слугувати самостійним юридичним фактом, що веде до переходу права власності, чи потрібна ще й передача речі, тобто необхідний цілий юридичний склад для настання відповідних правових наслідків. У публікації аналізуються категоpiї «розпорядчий правочин» та «речовий правочин», наводиться критика підходу щодо самостійності останнього як юридичного факту, що здатен спричинити перехід права власності. Розглянуті сутнісні особливості та проблеми застосування в цивілістиці абстрактної та каузальної моделей переходу речових прав за договором. Висловлені аргументи критики абстрактної моделі передачі речі, виявлені у практичній площині її реалізації, обгрунтовано виваженість законодавчого підходу щодо підтримки каузальної моделі переходу речових прав за договором. У роботі вирішується питання щодо самостійності правочину передачі речі в механізмі переходу права власності чи іншого речового права у ключі аналізу особливостей реальних та консенсуальних договорів. Сформульовано висновок, що в консенсуальному договорі передача речі становить виконання обов'язку, передбаченого договором, а для реального договору передача речі є невід’ємним елементом фактичного складу самого договору, без якої він уважатиметься неукладеним, тобто таким, що не існував, не відбувся. Для реального договору передачу речі варто розглядати не як самостійну та відірвану від правової підстави дію, здатну спричинити перехід речового права, а як елемент юридичного факту - договору, що тільки разом з останнім здатна спричинити перехід права власності. Відзначено, що передача речі не тотожна передачі права власності, для останньої зазвичай потрібний і обопільний намір, причому такий, що збігається, тобто укладення договору. Обгрунтовано, що договір є самостійним юридичним фактом, що здатен спричинити перехід права власності чи іншого речового права, хоча сам може мати складну структуру, елементами якої можуть виступати передача речі чи інші фактичні дії.

Ключові слова: передача речі, договір, перехід права власності, абстрактна та каузальна моделі переходу речового права за договором, речовий договір.

\section{Summary}

Hudyma M. M. Scientific discourse on the place of transfer of property in the mechanism of contractual transfer of ownership. - Article.

The scientific publication is devoted to the legal analysis of the meaning of the transfer of property in line with the theoretical doctrine of legal facts and the study of its place in the mechanism of contractual transfer of ownership. The article formulates the answer to the question: whether the contract can serve as an independent legal fact that leads to the transfer of ownership or the transfer of property is required, i.e. the whole legal structure is necessary for the relevant legal consequences. The publication analyzes the categories of «regulatory transaction" and "material transaction» and criticizes the approach to the independence of the latter as a legal fact that can lead to the transfer of ownership. The essential features and problems of application of abstract and causal models of transfer of property rights under the contract in civil law are considered. The author states the arguments of critique of the abstract model of transfer of property, revealed in the practical plane of its realization and the balance of the legislative approach concerning support of the causal model of transfer of property rights under the contract is substantiated. The issue of independence of the transaction of transfer of property in the mechanism of transfer of the property right or other property right through the prism of the analysis of features of real and consensual contracts is solved in the work. It is concluded that in a consensual contract the transfer of property is an obligation under the contract, and for a real contract - the transfer of property is an integral part of the actual composition of the contract itself, without which it will be considered unconcluded, i.e. nonexistent, which does not take place. For a real contract, the transfer of property should be considered not as an independent, detached from the legal basis action that can cause the transfer of property rights, but as an element of legal fact - a contract that only together with the latter can cause the transfer of ownership. It is noted that the transfer of property is not identical to the transfer of ownership; as the latter, generally, requires a mutual intention, the one that coincides, that is, the conclusion of the contract. It is substantiated that the contract is an independent legal fact that can cause the transfer of ownership or other property right, although it may have a complex structure, the elements of which may be the transfer of property or other actual actions.

Key words: transfer of property, contract, transfer of property right, abstract and causal models of transfer of property right under a contract, property contract. 